Full Length Article

\title{
Silver nanoparticles induced neurotoxicity through oxidative stress in rat cerebral astrocytes is distinct from the effects of silver ions
}

\author{
Cheng Sun ${ }^{a}$, Nuoya Yin ${ }^{a}$, Ruoxi Wen ${ }^{\mathrm{a}, \mathrm{b}}$, Wei Liu ${ }^{\mathrm{a}, \mathrm{c}}$, Yanxia Jia ${ }^{\mathrm{d}}$, Ligang $\mathrm{Hu}^{\mathrm{a}}$, \\ Qunfang Zhou ${ }^{\mathrm{a}, *}$, Guibin Jiang ${ }^{\mathrm{a}}$ \\ a State Key Laboratory of Environmental Chemistry and Ecotoxicology, Research Center for Eco-Environmental Sciences, Chinese Academy of Sciences, \\ Beijing 100085, PR China \\ ${ }^{\mathrm{b}}$ School of Earth and Space Science, University of Science and Technology of China, Anhui 230026, PR China \\ ${ }^{\mathrm{c}}$ Institute of Chemical Safety, Chinese Academy of Inspection and Quarantine, Beijing 100176, PR China \\ ${ }^{\mathrm{d}}$ Center for Biological Imaging, Institute of Biophysics, Chinese Academy of Sciences, Beijing 100101, PR China
}

\section{A R T I C L E I N F O}

\section{Article history:}

Received 9 June 2015

Received in revised form 6 September 2015

Accepted 14 September 2015

Available online 15 December 2015

\section{Keywords:}

Silver nanoparticle

Silver ion release

Particle effect

Neurotoxicity

Astrocyte

\begin{abstract}
A B S T R A C T
The rapid development of silver nanoparticles (AgNPs) based products has raised increasing concerns in view of their potential hazardous risks to the environment and human health. The roles of the released silver ions in AgNPs induced cytotoxicities are being hotly debated. Using rat cerebral astrocytes, the neurotoxicological effects of AgNPs and silver ions were investigated. Acute toxicity based on Alamar Blue assay showed that silver ions were considerably more toxic than AgNPs. Comparative studies indicated that AgNPs increased caspase activities and induced cell apoptosis under cytotoxic level of exposures, while silver ions compromised cell membrane integrity and dominantly caused cell necrosis. Cellular internalization of silver provided the basis for the cytotoxicities of these two silver species. In contrast to silver ions, intracellular reactive oxygen species (ROS) generation occurred in time- and concentration-dependent manners in astrocytes upon AgNPs stimulation, which caused subsequent cJun N-terminal kinases (JNK) phosphorylation and promoted the programmed cell death. Non-cytotoxic level of AgNPs exposure increased multiple cytokines secretion from the astrocytes, indicating that AgNPs were potentially involved in neuroinflammation. This effect was independent of silver ions as well. The distinct toxicological effects caused by AgNPs and silver ions provided the solid proofs for the particle-specific effects which should be concerned regarding the accurate assessment of AgNPs exposure risks.
\end{abstract}

() 2015 Elsevier Inc. All rights reserved.

\section{Introduction}

Silver nanoparticles (AgNPs) exhibit excellent antibacterial properties and are widely used nowadays in multiple areas including water disinfection, consumer products, pesticides and antimicrobials, medical diagnostics and pharmaceuticals (Chen and Schluesener, 2008). In view of the annual yield and nanomaterial based product variety, AgNPs rank first among all. More than 400 products containing nanosilver are now available for public use (Wilson, 2014). The incorporation of AgNPs in daily products will easily lead to leaching, which discharges into the environment. There are a myriad of ways for this kind of nanomaterials to be transported to multiple media and finally

\footnotetext{
* Corresponding author. Tel.: +86 1062849334

E-mail address: zhouqf@rcees.ac.cn (Q. Zhou).
}

reach to human beings. Accordingly, concerns have been raised currently regarding the potential toxicities of AgNPs and the risks versus benefits of nanosilver are being weighted (Nate, 2013). Substantial evidences have shown that AgNPs can cause respiratory tract toxicity, dermal toxicity, gastrointestinal tract toxicity, hepatoxicity, hematotoxicity, neurotoxicity, and ocular and visual system toxicity, etc. (EPA, 2010). Nevertheless, the particulate silver versus ionic silver controversy is still going on in view of the toxicological molecular mechanism of nanosilver (McShan et al., 2014), many research interests are concentrated on the influencing factors of particle size, shape and coatings though (Castranova, 2011). Contradictory conclusions have been drawn on AgNPs and the released ions involved cytotoxicities from laboratories around the world. Some people believed that ions, not particles made silver toxic based on the finding that the antibacterial activity of AgNPs was controlled by oxygen availability modulated silver ion release (Xiu et al., 2012). However, others pointed out that silver 
ion content of AgNPs suspension could not fully explain the observed toxicity (Kawata et al., 2009) and the substantial toxicities caused by some other metal ion free nanoparticles like gold nanoparticles (Siddiqi et al., 2012) demonstrated the particle effects of metal nanomaterials. The argument on how much toxicity of AgNPs is related to the particle per se is continued and it is much of importance to clarify the differences in toxicities of AgNPs and its released ions.

Recently, increasing reports have indicated that inhaled nanoparticles can reach the brain and it is thus necessary to evaluate their potential toxic effects on the neurological system (Win-Shwe and Fujimaki, 2011). Rats and mice receiving intraperitoneal, intravenous or intracerebroventricular administration of AgNPs showed pronounced brain edema in the affected regions with altered bloodbrain barrier function (Sharma et al., 2009). Increased incidence of astrocyte swelling and neuronal degeneration occurred in rats due to the accumulation of AgNPs (Tang et al., 2009). Using primary cultures of rat cerebellar granule cells (CGCs), the researchers observed that AgNPs incubation caused excitotoxicity in cultured neurons via activation of $N$-methyl-D-aspartate (NMDA) receptor, followed by calcium imbalance, mitochondrial dysfunction and reactive oxygen species (ROS) production (Ziemińska et al., 2014). Significant cellular toxicity in CGCs induced by AgNPs was mediated through programmed cell death coupled to oxidative stress (Yin et al., 2013). These proofs obtained from in vivo and in vitro tests provide the clues on how AgNPs directly interact with neurons and cause the deleterious effects. As we all know, astrocytes provide trophic and metabolic support to neurons, modulate synaptic activity and neuronal plasticity (Chen and Swanson, 2003), and they also influence neuronal survival through mediating neuroinflammation (Szydlowska et al., 2010). The role of astrocytes in AgNPs induced neurotoxicity is now also being recognized. Using primary mixed neural cell cultures, Haase et al. (2012) demonstrated astrocytes were much more vulnerable to AgNPs treatment compared with neurons. AgNPs were mainly taken up by astrocytes and they strongly affected the cell morphology. Although the timeand concentration-dependent accumulation of AgNPs in astrocytes did not compromise the cellular viability or the basal metabolism in contrast to the effect induced by the identical amounts of silver as $\mathrm{AgNO}_{3}$ (Luther et al., 2011, 2012), internalization of AgNPs in astrocytes through endocytotic uptake processes induced proinflammatory cytokine secretion for inflammatory responses (Huang et al., 2015) and the strong up-regulation of metallothioneins (Luther et al., 2012). The synthesized metallothioneins in astrocytes may store nanoparticle-derived silver ions, posing the potential protective effects in the brain (Hohnholt et al., 2013). Investigations on the potential biological effects of AgNPs in astrocytes are thus important to clarify glial cell involved neurotoxicity.

In this study, the neurotoxicity of AgNPs was evaluated using rat cortical astrocytes and the cellular responses to the nanoparticles exposure were compared with those of silver ions to elucidate the particle-specific effects. The findings provided new insights on the neurotoxicological effects of AgNPs and the released ions in astrocytes, which may shed light on their risk assessment on their potential hazards to the environment and human health.

\section{Materials and methods}

\subsection{Chemicals}

The suspension of AgNPs coated with polyvinylpyrrolidone (PVP, $10 \mathrm{mg} / \mathrm{mL}$ ) was commercially available from HuZheng Nanotechnology Limited Company (Shanghai, China). Silver nitrate $\left(\mathrm{AgNO}_{3}, 99.8 \%\right)$ was obtained from Sinopharm Chemical Reagent
Co., Ltd (China). The stock solutions $(1.0 \mathrm{mg} / \mathrm{mL}$ as $\mathrm{Ag}$ ) were made weekly in sterile distilled water and stored at $4{ }^{\circ} \mathrm{C}$ in darkness. AgNPs suspension was sonicated for $10 \mathrm{~min}$ to ensure its good dispersion before use. The exposure solutions of $\mathrm{AgNPs}$ and $\mathrm{AgNO}_{3}$ were freshly prepared by diluting the corresponding stock solutions in DMEM-F12 medium containing 0.1\% BSA. All concentrations were depicted in the unit of silver for both $\mathrm{AgNO}_{3}$ and AgNPs. The chemicals including $\mathrm{H}_{2} \mathrm{O}_{2}$, Triton X-100 were purchased from Sigma-Aldrich (USA) and used as the positive controls for the assays of caspase activity, flow cytometry, ROS generation, GSH depletion and extracellular LDH release, respectively. All the other necessary reagents, materials and kits were specified in the following methods.

\subsection{AgNPs characterization}

AgNPs were characterized by their morphology, hydrated particle size, zeta potential and UV absorbance. Several drops of sonicated AgNPs suspension were dispersed on the carbon membrane coated copper net and air dried. The samples were subsequently submitted to transmission electron microscopy observation at the accelerating voltage of $200 \mathrm{kV}$ (JEOL, 2100F, Japan) and the representative images were photographed at different magnifications. The hydrated particle size and zeta potential of AgNPs were measured by Malvern Zetasizer Nano ZS (Malvern, UK) in both water and DMEM-F12 cell exposure medium. The UV absorption of AgNPs suspension was measured by DU 800 (Beckman, USA) in the range of 300-700 nm. Silver ion release from AgNPs suspension was evaluated in both water and the cell exposure medium by a silver ion selective electrode (AgISE; JENCO, Shanghai, China).

\subsection{Cell culture}

As described previously (Kathryn et al., 2010), primary cultures of rat cerebral astrocytes were isolated from the cerebral cortex of 2-day old neonatal Sprague-Dawley rats. The animal research protocol was approved by the Animal Care and Use Committee of the Research Center for Eco-Environmental Sciences, Chinese Academy of Sciences. The fresh brain tissues were dissociated into a cell suspension using mechanical digestion and the cell suspension was grown in $75 \mathrm{~cm}^{2}$ culture flasks at $37{ }^{\circ} \mathrm{C}$ with $5 \%$ $\mathrm{CO}_{2}$ atmosphere for 12 days. The culture medium was DMEM F-12 (Hyclone, USA) containing fetal bovine serum (10\%, GIBCO, USA), antibiotics (penicillin $100 \mathrm{U} / \mathrm{mL}$ and streptomycin $100 \mu \mathrm{g} / \mathrm{mL}$, GIBCO, USA). The volume of medium in each flask was $15 \mathrm{~mL}$. The oligodendrocyte layer was disloged by shaking the flask and the subcultures of the remaining astrocytes within 10 passages were used for the subsequent exposure experiments. The robustness of the cell subcultures was guaranteed by the stable expression of astrocyte marker protein, glial fibrillary acidic protein (GFAP) in astrocytes at different passages (Fig. S1) using Western blot assays (Anti-GFAP antibody, 1:2000, Abcam, USA; rabbit anti-beta-actin antibody, 1:2000, Beijing Biosynthesis biotechnology). All the plates or dishes for cell cultures and exposure experiments were pre-coated with $0.1 \%$ gelatin (Millipore, USA) overnight and air dried in the sterile hood. Albumin is essential for the normal culture of astrocytes and inevitable in the real exposure scenarios. To eliminate the potential disturbance from high concentrations of serum in the medium, low serum culture medium ( $0.1 \%$ BSA) was used for all of the cell stimulations based on experiment optimization. Although both silver ions and AgNPs given to the incubation medium could partially bind to BSA and potentially low their availability for cellular uptake, the difference comparison on toxicological effects between these two silver species was not compromised as indicated below. 


\subsection{Alamar Blue assay}

The cells were plated in 96-well plates at the density of 10,000 cells/well with $200 \mu \mathrm{L}$ of medium per well and incubated for $24 \mathrm{~h}$. The stimulation was initiated by adding different concentrations of AgNPs and $\mathrm{AgNO}_{3}(0,0.01,0.1,0.5,1,5,10,20,40$ and $80 \mu \mathrm{g} / \mathrm{mL})$ in each well and the cells were exposed for $24 \mathrm{~h}$. Total $20 \mu \mathrm{L}$ of $10 \mu \mathrm{M}$ Alamar Blue reagent (Sigma-Aldrich, USA) was added into each well and incubated for $2 \mathrm{~h}$ in the dark. The fluorescence was measured at $\lambda_{\mathrm{Ex} / \mathrm{Em}}$ of $530 \mathrm{~nm} / 590 \mathrm{~nm}$ using a multifunction microplate reader (Thermo Scientific, VARIOSKAN FLASH, USA). The results were calibrated by the negative control and analyzed by plotting the calibrated values versus the chemical concentrations. The potential influence of nanoparticles on the fluorescence measurement was evaluated by comparing the fluorescence changes between the resorufin with and without AgNPs (1$80 \mu \mathrm{g} / \mathrm{mL}$ ). The result showed no disturbance was caused on the fluorescent measurement by AgNPs per se at the tested concentrations up to $80 \mu \mathrm{g} / \mathrm{mL}$ in this study (Fig. S2), confirming the feasibility of this assay in evaluating the effects of nanoparticles on cell viabilities.

\subsection{Extracellular lactate dehydrogenase (LDH) release test}

Similar to the cell treatment in Alamar Blue assay, the cells in 96-well plates were stimulated with $\operatorname{AgNPs}(0,0.01,0.1,1$ and $10 \mu \mathrm{g} / \mathrm{mL})$ and $\mathrm{AgNO}_{3}(0,0.01,0.1$ and $1 \mu \mathrm{g} / \mathrm{mL})$ for $24 \mathrm{~h}$. Trix-100 $(0.5 \%)$, as the positive control, was used to treat the cells for $2 \mathrm{~min}$. After exposure, $100 \mu \mathrm{L}$ of cell culture medium in each well was transferred to a new 96-well plate for extracellular LDH measurement using commercial available LDH assay kit (Promega, USA). Release of LDH from damaged cells was measured by supplying lactate, $\mathrm{NAD}^{+}$, and resazurin as substrates in the presence of diaphorase. Generation of the fluorescent resorufin product was proportional to the amount of LDH in the samples. As the accuracy of this enzymatic method may be directly interfered by the chemicals in the samples (Wright et al., 2014), potential interferences of AgNPs and silver ions were thus investigated by using Trixon-100 lysed cell samples as the LDH source. Different concentrations of AgNPs and silver ions (0, 0.01, 0.1, 1 and $10 \mu \mathrm{g} /$ $\mathrm{mL}$ ) were added in Trixon-100 lysed LDH samples before they were submitted to the kit analysis. The fluorescence intensity decrease was evaluated by the comparison with the control sample without chemical addition. The results showed that AgNPs at the tested concentration range $(0.01-10 \mu \mathrm{g} / \mathrm{mL})$ had no influences on LDH assay, while silver ions at $10 \mu \mathrm{g} / \mathrm{mL}$ significantly decreased the fluorescence emission due to the potential inhibition of the enzyme activities by silver ions in the detection system (Fig. S3). The exposure concentrations ranging from 0.01 to $1 \mu \mathrm{g} / \mathrm{mL}$ were accordingly selected for silver ions in this assay.

\subsection{Live-Dead cell staining}

Astrocytes were cultured in the glass bottom cell culture dishes (35 mm, NEST) at the density of 100,000 cells/well with $2 \mathrm{~mL}$ of medium per dish for $24 \mathrm{~h}$. The stimulations of AgNPs $(10 \mu \mathrm{g} / \mathrm{mL})$ and silver ions $(1 \mu \mathrm{g} / \mathrm{mL})$ were performed for $24 \mathrm{~h}$ and the cells were subsequently submitted to the staining using Live-Dead Cell Staining kit (Biovision, USA). A cell-permeable green fluorescent dye, calcein AM, was used to determine live cells and propidium iodide (PI), a cell non-permeable red fluorescent dye, easily stained the dead ones. Stained live and dead cells were visualized by confocal fluorescence microscope (Leica SP5, USA) using dual channel optical path ( $\lambda_{\mathrm{Ex} / \mathrm{Em}}: 488 \mathrm{~nm} / 525 \mathrm{~nm}$ and $488 \mathrm{~nm} /$ $615 \mathrm{~nm})$.

\subsection{Caspase activity evaluation}

The astrocytes were cultured in 12-well plates at the density of 50,000 cells/well with $1 \mathrm{~mL}$ of medium per well. When the confluence reached to around $80 \%$ after $24 \mathrm{~h}$ incubation, AgNPs (0, $0.01,0.1,1$ and $10 \mu \mathrm{g} / \mathrm{mL})$ and silver ions $(0,0.01,0.1$ and $1 \mu \mathrm{g} / \mathrm{mL})$ were applied to different wells and the treatments lasted for $24 \mathrm{~h}$. $\mathrm{H}_{2} \mathrm{O}_{2}$ (1 mM), as the positive control, was used to stimulate the cells for $1 \mathrm{~h}$. When the exposure was terminated, the cells were washed with PBS three times and lysed with the protein extraction buffer ( $25 \mathrm{mM}$ HEPES at pH 7.5, 0.1\% CHAPS, $100 \mathrm{U} / \mathrm{mL}$ aprotinin) on ice for $20 \mathrm{~min}$. The samples were centrifuged $(12,000 \times \mathrm{g}$, $15 \mathrm{~min}, 4^{\circ} \mathrm{C}$ ) and the supernatant were submitted to protein concentration analysis by BCA assay (Thermo, Pierce, USA). Approximate $30 \mu \mathrm{g}$ of protein was mixed with $50 \mu \mathrm{M}$ Z-DEVEAFC substrate (Millipore, USA) in $100 \mu \mathrm{L}$ of reaction buffer $(25 \mathrm{mM}$ HEPES at $\mathrm{pH} 7.5,0.1 \%$ CHAPS, $100 \mathrm{U} / \mathrm{mL}$ aprotinin). The fluorescence was monitored at the interval of $5 \mathrm{~min}$ for $30 \mathrm{~min}$ at room temperature by a multifunction microplate reader $\left(\lambda_{\mathrm{Ex} / \mathrm{Em}}\right.$ : $400 \mathrm{~nm} / 505 \mathrm{~nm}$ ).

\subsection{Cell apoptosis and necrosis analysis}

The astrocytes were cultured in $100 \mathrm{~mm}$ culture dishes at the density of 500,000 cells/dish with $10 \mathrm{~mL}$ of medium per dish for $24 \mathrm{~h}$. Similar to the cell treatment for caspase activity assay, the cells were stimulated with AgNPs $(0,1$ and $10 \mu \mathrm{g} / \mathrm{mL})$ and silver ions $(0,0.1$ and $1 \mu \mathrm{g} / \mathrm{mL})$ for $24 \mathrm{~h}$, respectively. $\mathrm{H}_{2} \mathrm{O}_{2}(1 \mathrm{mM}, 1 \mathrm{~h})$, as the positive control, was tested for the assay validation. After the digestion using $0.25 \%$ trypsin (Thermo, USA), the detached cells were washed with ice-cold HBSS twice and stained with $5 \mu \mathrm{L}$ of Annexin-V FITC (BD Biosciences, USA) for $15 \mathrm{~min}$ at room temperature in darkness. The single cell suspension was doubled stained with $5 \mu \mathrm{L}$ of PI before the cell apoptosis measurement using BD FACS Calibur flow cytometer (BD Biosciences, USA).

\subsection{Cellular silver analysis by inductively coupled plasma mass spectrometry (ICP-MS)}

The subcultures of astrocytes plated in $100 \mathrm{~mm}$ dishes were exposed to silver ions $(0,0.1$ and $1 \mu \mathrm{g} / \mathrm{mL})$ and AgNPs $(0,1$ and $10 \mu \mathrm{g} / \mathrm{mL}$ ) for $4 \mathrm{~h}$ when the dose-related silver internalization was evaluated. The treatments of astrocytes with silver ions and AgNPs $(1 \mu \mathrm{g} / \mathrm{mL})$ were also performed for 4 and $24 \mathrm{~h}$, respectively, to investigate the time course for cellular silver accumulation. The exposure medium was discarded and the cells were gently washed with PBS twice. Considering the non-specific attachment of substantial amounts of chemicals on the cell surface, the cell lysates, rather than the whole cell samples, were used to evaluate cellular internalization of these two silver species. In particular, the stimulated cells from each group were harvested using $300 \mu \mathrm{L}$ of lysis buffer ( $10 \mathrm{mM}$ Tris- $\mathrm{HCl}$ containing $10 \%$ glycerol, $1 \%$ Triton X100 , pH 7.4). After centrifugation $(12,000 \times \mathrm{g}, 20 \mathrm{~min})$, the cell lysate was digested with the mixture of $65 \%$ nitric acid and $30 \%$ $\mathrm{H}_{2} \mathrm{O}_{2}$ at $95{ }^{\circ} \mathrm{C}$ for $1 \mathrm{~h}$. The digested sample was diluted to $4 \mathrm{~mL}$ and the total silver content was quantitatively measured by ICP-MS (Agilent 8800, USA). The final value was calibrated with the protein concentration measured by Pierce BCA kit (Thermo, USA).

\subsection{AgNPs internalization visualized with transmission electron microscopy (TEM)}

To further confirm the presence of AgNPs in astrocytes, TEM was used to observe the distribution of intracellular AgNPs. The astrocytes cultured in $100 \mathrm{~mm}$ dishes from the control and AgNPs groups ( $1 \mu \mathrm{g} / \mathrm{mL}, 24 \mathrm{~h}$ ) were carefully trypsinized and collected. 
After centrifugation, the cell pellets were gently fixed with $0.1 \mathrm{M}$ natrium cacodylicum (Sigma) for $12 \mathrm{~h}$, then washed three times with cold PBS and post-fixed with 1\% osmium tetroxide for $4 \mathrm{~h}$. Ultra-thin sections for TEM were prepared and the specimens were double stained by lead citrate and uranyl acetate. Finally, the samples were observed and photographed using TEM at the accelerating voltage of $100 \mathrm{kV}$ (Tecnai Spirit, USA).

\subsection{Intracellular ROS assay}

The astrocytes cultured in 24-well plates at the density of 25,000 cells/well with $500 \mu \mathrm{L}$ of medium per well were stimulated with $1 \mu \mathrm{g} / \mathrm{mL}$ AgNPs and $0.1 \mu \mathrm{g} / \mathrm{mL}$ silver ions for $0,0.5,1,4$ and $24 \mathrm{~h}$, respectively, to evaluate the time course for intracellular ROS generation. As suggested by the specification of $2^{\prime}, 7^{\prime}$-dichlorodihydrofluorescein (DCFH-DA, Sigma, USA), this fluorescent probe was pre-loaded in the cells before the chemical stimulation for time points of 0.5 and $1 \mathrm{~h}$. As for the others, $100 \mu \mathrm{M}$ DCFH-DA was applied to the cells after stimulation and the incubation was continued for $30 \mathrm{~min}$ at $37{ }^{\circ} \mathrm{C}$ in $5 \% \mathrm{CO}_{2}$. The intracellular ROS was evaluated by measuring the fluorescence at $\lambda_{\mathrm{Ex} / \mathrm{Em}}$ of $488 \mathrm{~nm} /$ $525 \mathrm{~nm}$. The positive control, $\mathrm{H}_{2} \mathrm{O}_{2}(1 \mathrm{mM})$ was also tested to confirm the feasibility of this assay. When the dose-response was investigated, a series of concentrations of $\mathrm{AgNO}_{3}$ and $\mathrm{AgNPs}(0$, $0.01,0.1$, and $1 \mu \mathrm{g} / \mathrm{mL}$ ) were used to stimulate the astrocytes for $4 \mathrm{~h}$. The representative images were photographed for cell samples from the control, silver ions $(0.1 \mu \mathrm{g} / \mathrm{mL}, 4 \mathrm{~h})$ and AgNPs $(1 \mu \mathrm{g} / \mathrm{mL}$, $4 \mathrm{~h}$ ) treated groups using inverted fluorescent microscope (Zeiss, Germany). Considering the antioxidant role of DCFH-DA, it may directly react with the chemicals with oxidative properties. Influences of AgNPs and silver ions on the fluorescence generation of DCFH-DA in cell free conditions were evaluated as well. The result showed that silver ions induced dose-dependent oxidation of DCFH-DA in the medium, thus increasing the fluorescence emission at $525 \mathrm{~nm}$ (Fig. S4). In contrast, AgNPs at equivalent concentrations $(0.01,0.1$ and $1 \mu \mathrm{g} / \mathrm{mL})$ had little effect except the slight elevation of fluorescence emission in $10 \mu \mathrm{g} / \mathrm{mL}$ AgNPs group (Fig. S4). It was probably due to silver ion release in the relatively high concentration of AgNPs suspension. This finding indicated that silver ions are more potent to oxidize the probe, while AgNPs are relatively inert. Possible interferences from the probe oxidation in vitro needed to be considered when the intracellular ROS generation was evaluated.

\subsection{Cellular glutathione (GSH) assay}

The cells used for GSH depletion assay were stimulated using the protocol similar to Alamar Blue assay. The reduced GSH levels in astocytes were determined by Glutathione Assay Kit according to the manufacturer's introduction (Promega, USA) after the exposure to a series concentrations of AgNPs and silver ions ( 0 , $0.01,0.1,1$ and $10 \mu \mathrm{g} / \mathrm{mL}$ ) for $4 \mathrm{~h} . \mathrm{H}_{2} \mathrm{O}_{2}$ stimulation $(1 \mathrm{mM}, 1 \mathrm{~h}$, positive control) caused complete depletion of cellular GSH (2.56\% of control), showing the feasibility of GSH assay for the exposed astrocytes. The alteration in cellular GSH levels was evaluated by the ratio of each group to the negative control.

\subsection{Evaluation of JNK phosphorylation}

The cells were seeded in 6-well plates at the density of 10,000 cells/well with $2 \mathrm{~mL}$ of medium per well and cultured till the confluence reached to approximate $80-90 \%$. The cells were starved for $4 \mathrm{~h}$ in $2 \mathrm{~mL}$ of low serum culture medium (0.1\% BSA, Sigma, USA). The stimulation was initiated by the addition of AgNPs $(0$, $0.01,0.1,1,10$ and $20 \mu \mathrm{g} / \mathrm{mL})$ and silver ions $(0,0.001,0.01,0.1$ and $1 \mu \mathrm{g} / \mathrm{mL}$ ) and the exposure lasted for $2 \mathrm{~h}$. After treatment, the cells were washed with ice-cold PBS for three times and lysed with $100 \mu \mathrm{L}$ of lysis buffer supplemented with protease inhibitor cocktail (Sigma, USA). Equal amount of the protein sample from each group was submitted to the SDS-PAGE separation (10\%), nitrocellulose membrane (Millipore, USA) transfer, primary antibody blotting (Phospho-JNK and JNK, Cell Signaling, 1:1000), secondary antibody incubation (goat anti rabbit IgG, Cell Signaling Technology, USA, 1:2000), and final development with Pierce ECL (Thermo Scientific, USA). The pixel densities on the developed Xray film were evaluated by Quantity One software.

\subsection{Cytokine array}

The astrocytes plated in $60 \mathrm{~mm}$ culture dish at the density of 300,000 cells/dish with $5 \mathrm{~mL}$ of medium per dish were incubated for $24 \mathrm{~h}$ and subsequently stimulated with AgNPs $(1 \mu \mathrm{g} / \mathrm{mL})$ and silver ions $(0.1 \mu \mathrm{g} / \mathrm{mL})$ for $24 \mathrm{~h}$ and the culture medium was collected for the analysis of cytokines using Proteome Profiler ${ }^{\mathrm{TM}}$ Rat Cytokine Arrays (R\&D Systems, USA). The array procedure was performed carefully according to the manufacturer's instruction. Briefly, the membranes were blocked for $1 \mathrm{~h}$ and subsequently submitted to overnight blotting $\left(4^{\circ} \mathrm{C}\right)$ using the collected medium samples which were pre-incubated with the detection antibody cocktail for $1 \mathrm{~h}$. After washing, the membranes were incubated with Streptavidin-HRP solution for $30 \mathrm{~min}$ at room temperature and finally developed using Chemi Reagent Mix on the X-ray film. Quantity One software was used to analyze the pixel densities on the developed X-ray film.

\subsection{Statistical analysis}

Each assay was performed independently for three times $(N=3)$. Triplicate parallel wells or dishes $(n=3)$ were designed for each condition during every test. The final results were expressed as the mean values with standard deviations. Differences between the negative controls and silver species exposed groups were analyzed by unpaired Student's $t$-test. The significant difference was indicated by $p$-value less than 0.05 or 0.01 versus control.

\section{Results}

\subsection{AgNPs characterization}

The physcial characters of AgNPs in both water and exposure medium were tested to clarify if the cell culture medium system would affect the morphoragy and the dispersion of the tested nanoparticles. The TEM images revealed that similar sphere particles of AgNPs were uniformly dispersed without obvious aggregation (Fig. S5A-1 and S5A-2). The average partilce sizes were $24.18 \pm 4.14 \mathrm{~nm}$ in water and $23.18 \pm 4.17 \mathrm{~nm}$ in cell exposure medium, respectively. The dynamic light scattering (DLS) measurement indicated that hydrated sizes of the nanoparticles were $33.36 \pm 0.55 \mathrm{~nm}$ with the polydispersity index (PDI) of 0.191 in water and $21.54 \pm 0.10 \mathrm{~nm}$ with PDI of 0.272 in the medium (Fig. S5B1 and S5B-2). The low PDI in both tested systems showed that the polydiversity of AgNPs was acceptable in view of investigations on monodiverse particles. The charaterisc absorbance of AgNPs was also monitored and the results depicted in Fig. S5C- 1 and S5C-2 showed the maximum absorbance of AgNPs had a little bit red shift in the exposure medium $\left(\lambda_{\max }: 414 \mathrm{~nm}\right)$ when compared to that in the water system ( $\left.\lambda_{\max }: 408 \mathrm{~nm}\right)$. Zeta potentials of AgNPs in water and medium were $-0.17 \mathrm{mV}$ and $-0.19 \mathrm{mV}$, respectively, showing the features of AgNPs were very close in both dispersion systems. The release rate of silver ions from AgNPs suspension was also evaluated as this could influece the biological effects observed in AgNPs expsoure system. Based on the calibration curves of silver ions in the 
absence $\left(\mathrm{H}_{2} \mathrm{O}\right)$ and presence of BSA (exposure medium) (Fig. S6), the silver ion release ratios accounted for $1-2 \%$ of AgNPs in both dispersion systems when the concentrations were set at 1 and $10 \mu \mathrm{g} /$ $\mathrm{mL}$, respectively (Table S1).

\subsection{Cell viability and morphology alterations}

Using Alamar Blue assay, the cell viability was analyzed for the cells treated with a series of concentrations of AgNPs and $\mathrm{AgNO}_{3}$ for $24 \mathrm{~h}$. The result in Fig. $1 \mathrm{~A}$ showed that both AgNPs and $\mathrm{AgNO}_{3}$ induced dose-dependent decreases in the cell viability and the half-maximal inhibitory concentrations $\left(\mathrm{IC}_{50}\right)$ of $\mathrm{AgNPs}$ and $\mathrm{AgNO}_{3}$ were $9.79 \pm 0.46$ and $1.29 \pm 0.86 \mu \mathrm{g} / \mathrm{mL}$, respectively. No observable effect concentrations (NOEC) were 1 and $0.1 \mu \mathrm{g} / \mathrm{mL}$ for AgNPs and $\mathrm{AgNO}_{3}$, separately. The cell membrane integrity was evaluated by measuring the extracellular $\mathrm{LDH}$ release and the results are depicted in Fig. 1B. It was clearly demonstrated that AgNPs did not damage the cell membrane at the tested concentration range $(0.01-10 \mu \mathrm{g} / \mathrm{mL})$ as there was no significant change in extracellular LDH level when compared to the control. In contrast, when the cells were exposed to $\mathrm{AgNO}_{3}(0.1$ and $1 \mu \mathrm{g} / \mathrm{mL}), \mathrm{LDH}$ release elevated significantly, showing silver ions could cause cytotoxicity through the membrane breakage. Morphological image from Fig. 1C-1 showed that the control cells were well distributed in the dishes with the clear flat polygonal cell bodies and normal round nucleus. The cells after 24-h treatment with $1 \mu \mathrm{g} / \mathrm{mL} \mathrm{AgNO}_{3}$ (Fig. 1C-2) turned small and round with obvious broken cell boundaries. Some dead ones were floating in the medium, which were presented as the bright dots in the images. Comparatively, AgNPs exposure $(10 \mu \mathrm{g} / \mathrm{mL}, 24 \mathrm{~h}$, Fig. 1C-3) caused the shrinkage of the cell bodies with some floating dead ones.

\subsection{Cytotoxicity based on Live-Dead cell staining}

In view of the investigation on growth control and cell death, the astrocytes were treated with silver ions $(1 \mu \mathrm{g} / \mathrm{mL})$ and AgNPs $(10 \mu \mathrm{g} / \mathrm{mL})$ for $24 \mathrm{~h}$ and stained with the Live-Dead cell staining kit to distinguish between live cells and dead ones. Fig. 2A shows abundant green stained cells (Fig. 2A-1) with negligible red stained cells (Fig. 2A-2) in the negative control and the overlay image
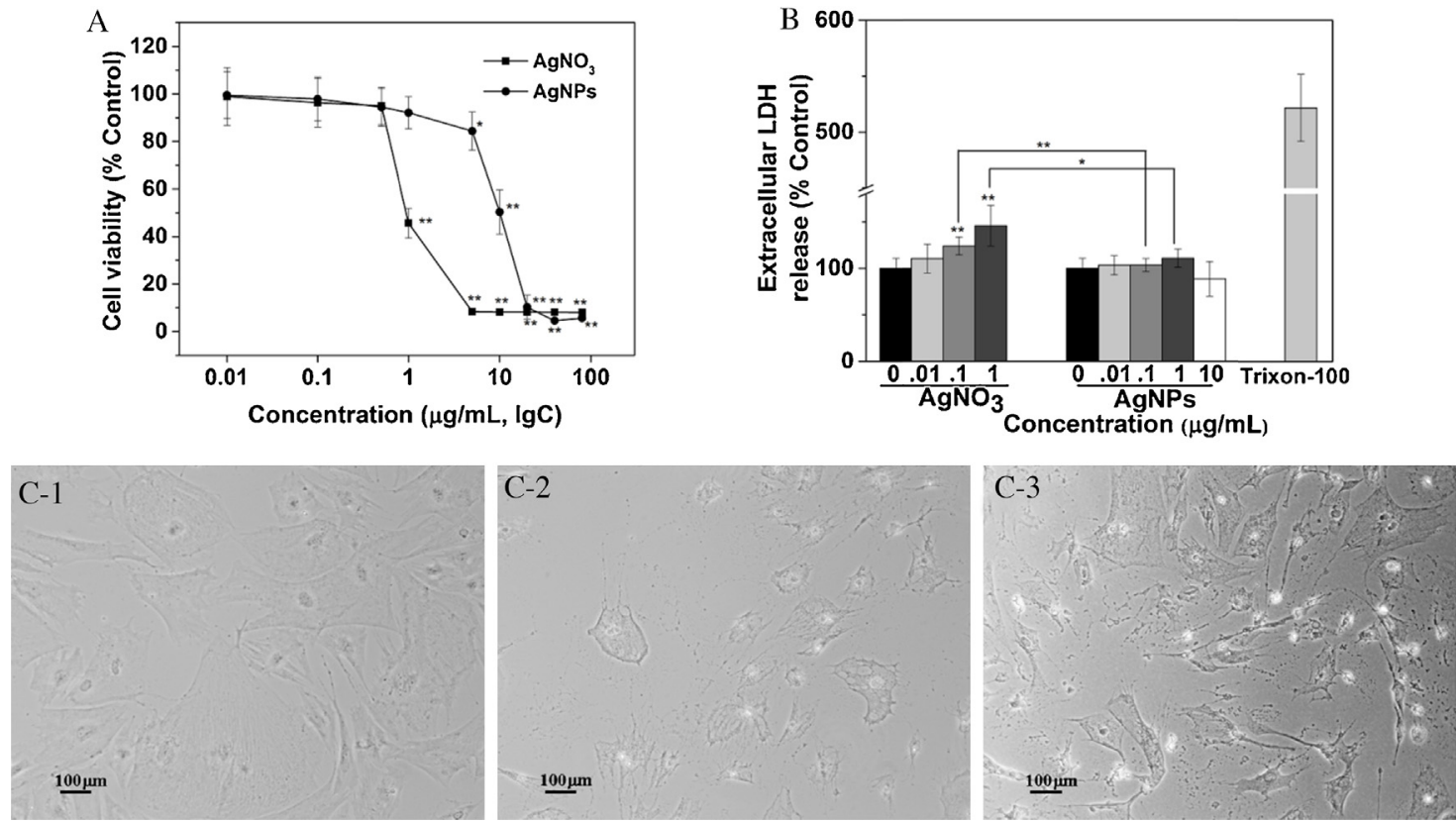

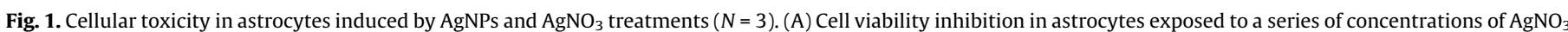

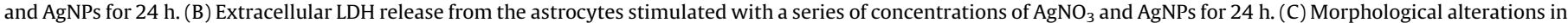
astrocytes after 24-h treatments with $\mathrm{AgNO}_{3}$ and AgNPs (C-1: Control, C-2: $1 \mu \mathrm{g} / \mathrm{mL} \mathrm{AgNO}_{3}, \mathrm{C}-3: 10 \mu \mathrm{g} / \mathrm{mL}$ AgNPs). ${ }^{*} p<0.05$ and ${ }^{* *} p<0.01$ versus control.
(Fig. 2A-3) showed the live cells (green) were well distributed in the visual fields. When treated with silver ions, the number of live cells decreased to some extent (Fig. 2B-1) and PI stained dead cell number increased strikingly when compared to the control (Fig. 2B-2). A substantial amount of the cells turned yellow in the overlay (Fig. 2B-3), showing the obvious cytotoxicity was induced by silver ions. Similarly, the images from AgNPs treated group distinctly showed the decreased proportion of live cells and increased amount of dead ones (Fig. 2C), indicating AgNPs at the concentration nine times higher than silver ions caused approximately equal cytotoxicity in astrocytes to ionic silver species.

\subsection{Cell necrosis and apoptosis}

Caspase activity was monitored for silver ions and AgNPs treated astrocytes to evaluate the potential effect of cell apoptosis. The result shown in Fig. $3 \mathrm{~A}$ indicated that $1 \mathrm{mM} \mathrm{H}_{2} \mathrm{O}_{2}$ significantly increased caspase activity in astrocytes after 1 -h stimulation, proving oxidative stress induced cell apoptosis. In view of $\mathrm{AgNO}_{3}$ and AgNPs treatments, no alterations in caspase activity of astrocytes were found under non-cytoxic exposure levels of the stimulants (0.01-0.1 $\mu \mathrm{g} / \mathrm{mL}$ for $\mathrm{Ag}^{+}$and $0.01-1 \mu \mathrm{g} / \mathrm{mL}$ for AgNPs), while the caspase activities were elevated in astrocytes under cytotoxic levels of silver ions $(1 \mu \mathrm{g} / \mathrm{mL})$ and AgNPs $(10 \mu \mathrm{g} / \mathrm{mL})$ exposures. Comparatively, AgNPs exposure had relatively severer effect on caspase activity increase than silver ions did, implying the higher potential of AgNPs in inducing cell apoptosis when the equivalent cytotoxicity was controlled (Fig. 1A and 2). Cell apoptosis and necrosis were further investigated by flow cytometry. Fig. 3B and C- 1 shows that the percentage of the live and healthy cells in Q3 phase accounted for $91.25 \%$ in the negative control, that of the early and late apoptotic or necrotic cells in Q2 and Q4 were 6.85\%, and that of the necrotic cell fragments in Q1 phase was $1.80 \%$ of the total. The positive control, $\mathrm{H}_{2} \mathrm{O}_{2}(1 \mathrm{mM}, 1 \mathrm{~h})$ significantly increased both late apoptotic and necrotic cells (Q4 and Q1), while the live cells (Q3) decreased (Fig. 3B and C-4), confirming the feasibility of the experimental model in cell apoptosis and necrosis analysis. Regarding the effects from silver ions and AgNPs, the cell percentages in four phases were distinctly

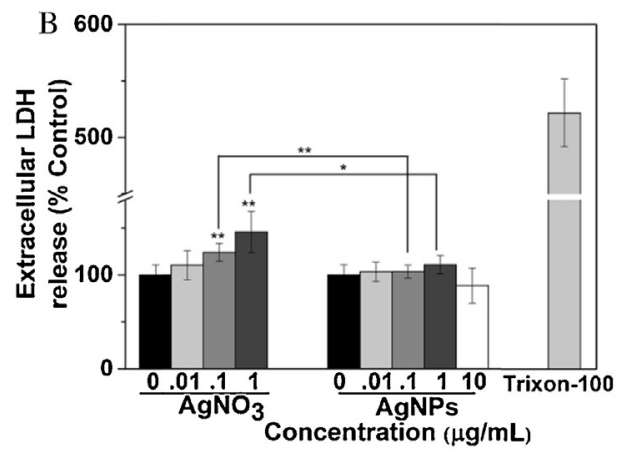



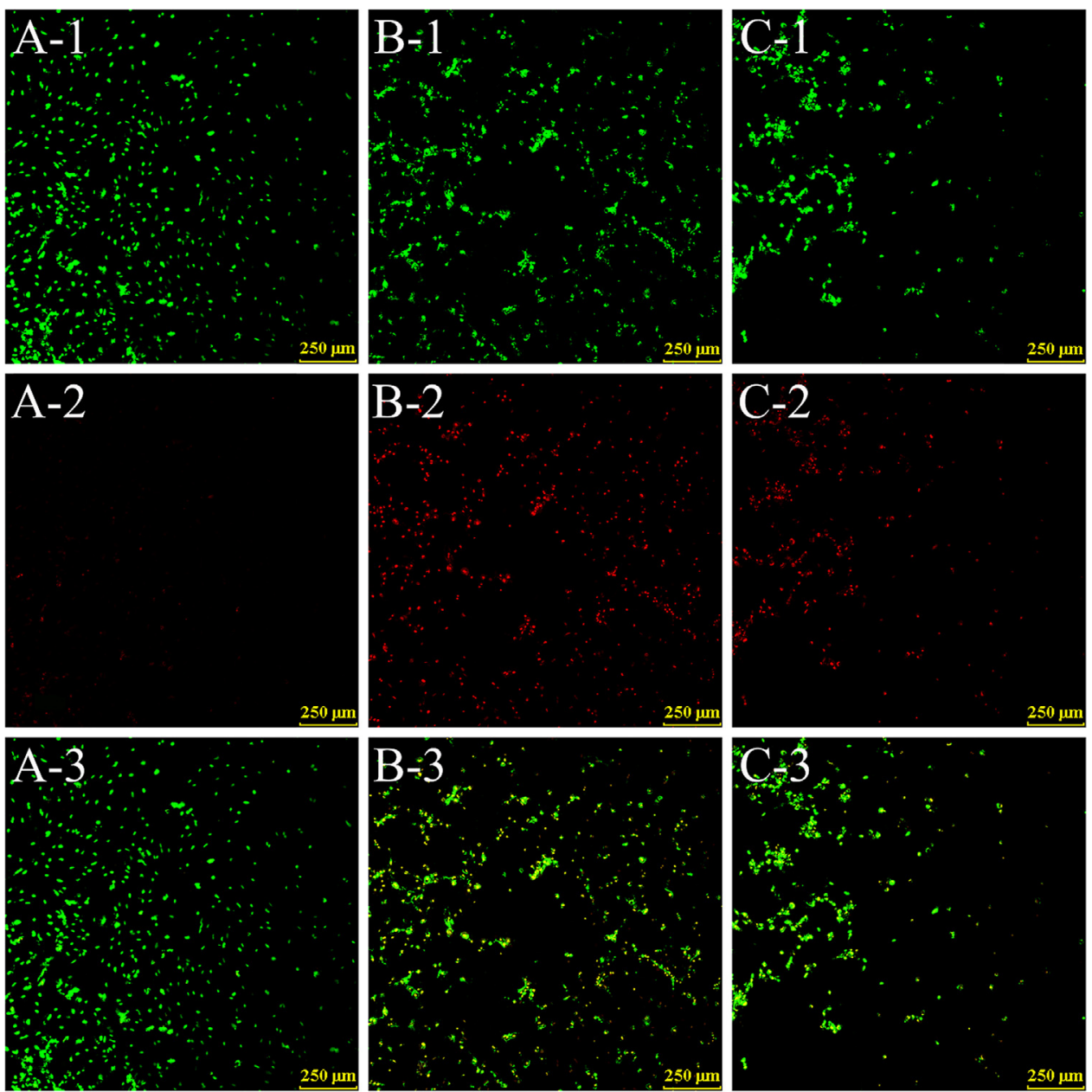

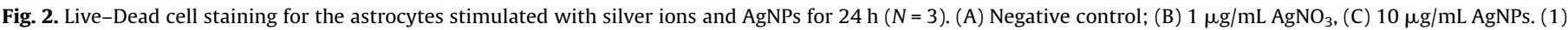
Calcein AM stained live cells; (2) PI stained dead cells; (3) Overlay of the Image (1) and (2).

altered upon cytotoxic stimulations $\left(1 \mu \mathrm{g} / \mathrm{mL} \mathrm{AgNO}_{3}, 10 \mu \mathrm{g} / \mathrm{mL}\right.$ AgNPs). Silver ions caused more cell necrosis concomitant with apoptosis evidenced by significant increase in Q1 of $17.03 \%$ and Q2 plus Q4 of $50.00 \%$ (Fig. 3B and C-2). Comparatively, AgNPs induced effect was dominated by cell apoptosis, as indicated by the obvious increase in early apoptotic cell numbers in Q4 (40.90\%, Fig. 3B and $\mathrm{C}-3)$. This finding was consistent with the result from caspase activity study.

\subsection{Silver internalization}

Silver internalization may help to explain the cytotoxicities observed above. Both dose-response and time course for silver accumulation in astrocytes were investigated. Fig. 4A indicates that silver was uptaken by astrocytes effectively in a dose-related manner for both silver ions and AgNPs after 4-h exposures. When the stimulation period was investigated for silver internalization, it was found that silver levels increased with the prolonged exposure time (Fig. 4B). Relatively higher level of $\mathrm{Ag}$ was detected in $\mathrm{AgNO}_{3}$ exposed cells when compared to AgNPs treated ones within relatively short time ( $4 \mathrm{~h}$ ), showing silver ions might enter into the cells more rapidly than the nanopartilces. However, when the values at $24 \mathrm{~h}$ were compared, Ag level in AgNPs group was a little bit higher than that in $\mathrm{AgNO}_{3}$ group, indicating that AgNPs might have higher bioaccumulation ability than silver ions. As shown in Fig. 4C-2, TEM observation for the cell cultures from the control and AgNPs exposure groups further confirmed AgNPs could enter into the astrocytes in particulate forms and they deposited in the cytoplasmic phagocytotic vesicles.

\subsection{Oxidative stress}

As the distinct toxicological responses in oxidative stress were declared for silver ions and AgNPs induced cytotoxicity (Choi and $\mathrm{Hu}, 2008$ ), intracellular ROS generation was evaluated in astrocytes upon the stimulations of silver ions and AgNPs. Fig. 5A illustrates that, similar to the positive control, $\mathrm{H}_{2} \mathrm{O}_{2}, \mathrm{AgNPs}$ exposure caused elevated ROS levels in the cells in the timedependent manner, while silver ions had undetectable alterations in ROS generation within $24 \mathrm{~h}$. Fig. 5B shows, contrary to silver ions, AgNPs caused intracellular ROS generation increase in a dosedependent manner. This phenomenon was distinct from the finding described above in Fig. S4, proving that cellular ROS generation probed by DCFH-DA in AgNPs stimulated astrocytes was independent of the disturbance from the direct oxidative interaction between chemicals and the probe. The images in Fig. 5C-3 showed AgNPs stimulated astrocytes were probed by bright green fluorescence. However, the cells with the treatments of silver ions had little fluorescence emission, which was similar to the negative controls. This finding further confirmed AgNPs induced intracellular ROS generation rather than silver ions. Depletion of the antioxidant GSH is one of the indices of oxidative stress as well (Mytilineou et al., 2002). The assessment on cellular GSH levels showed that silver ion treatments for $4 \mathrm{~h}$ 

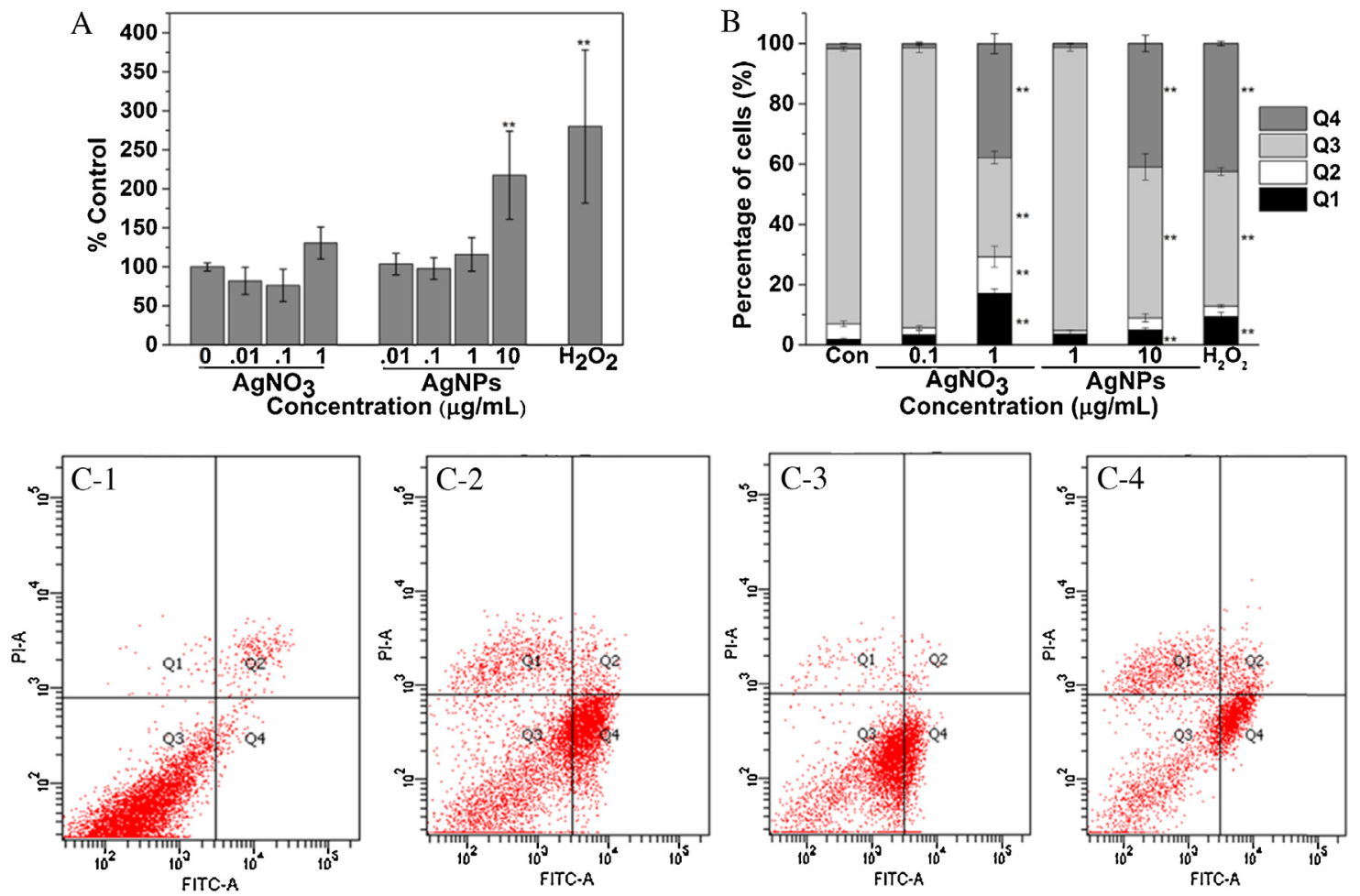

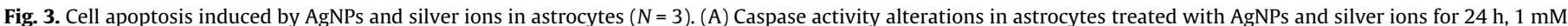

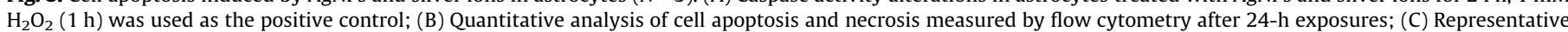

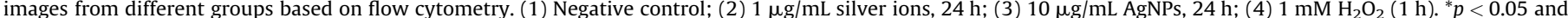
${ }^{* *} p<0.01$ versus control.
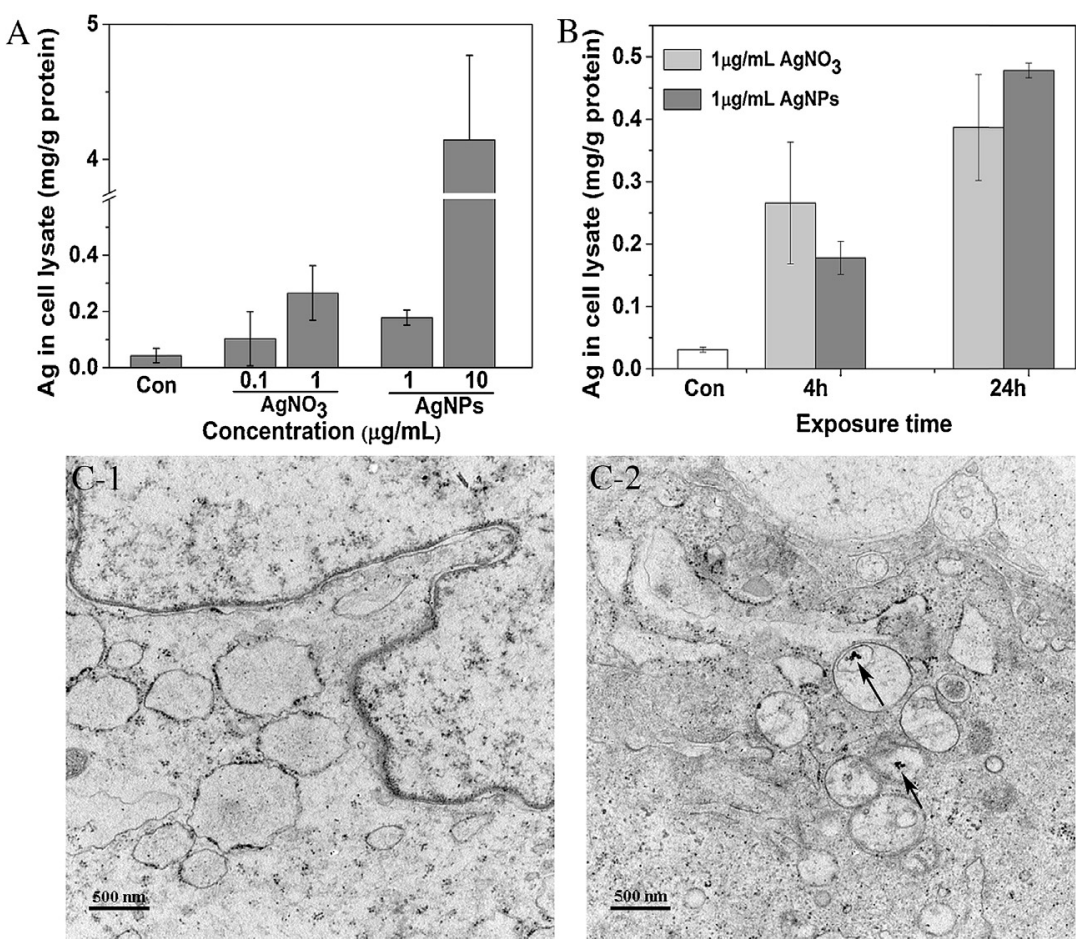

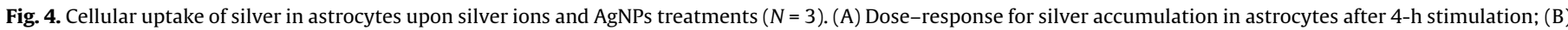

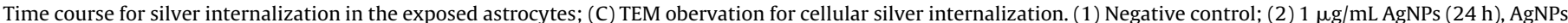
deposited in the phagocytotic vesicles as indicated by the black arrows. 

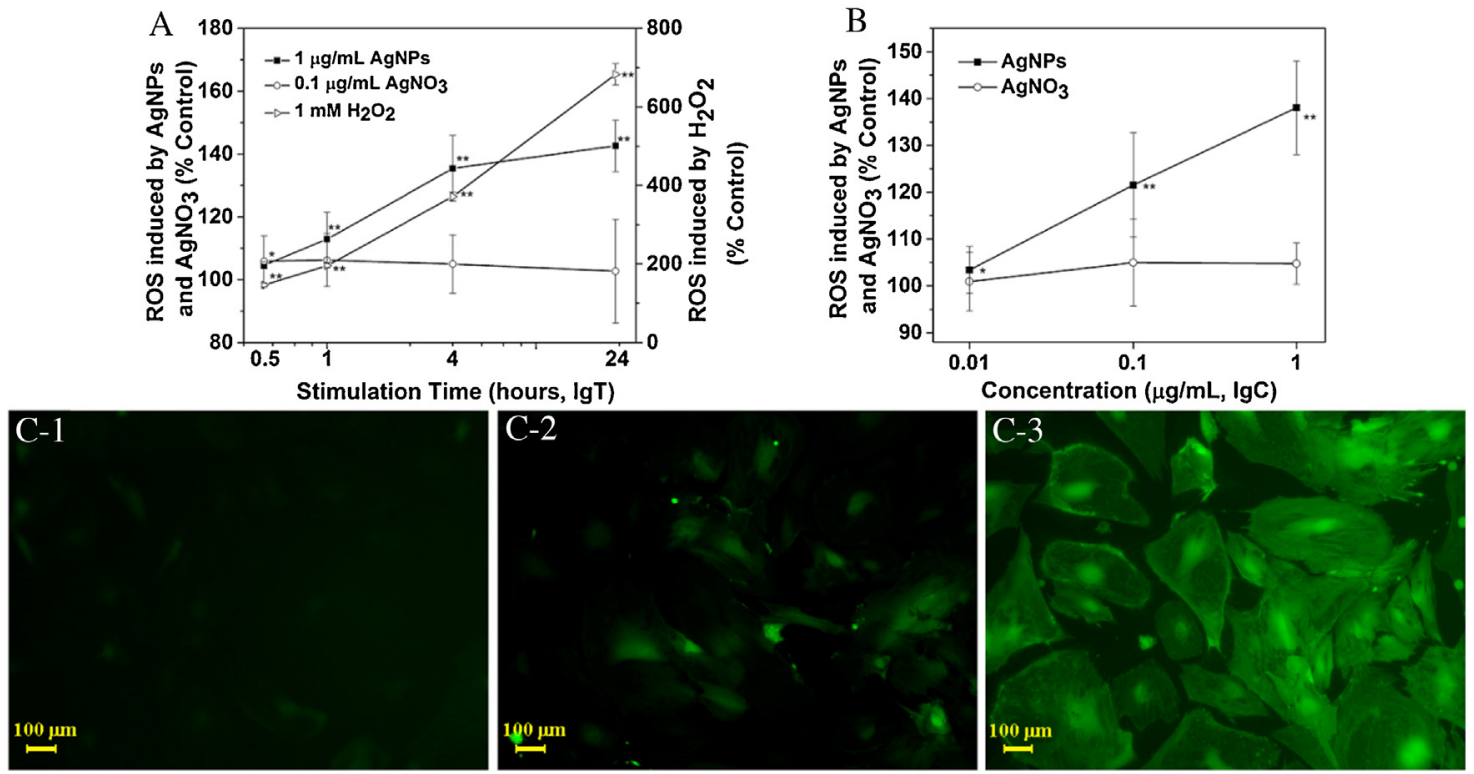

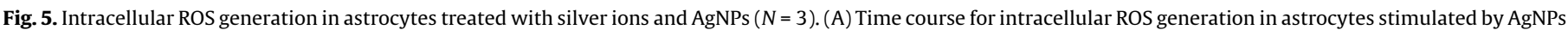

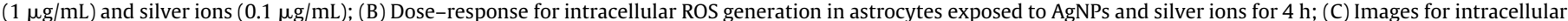
ROS generation in astrocytes after 4-h exposure, (1) Negative control, (2) $0.1 \mu \mathrm{g} / \mathrm{mL} \mathrm{AgNO}_{3}$, (3) $1 \mu \mathrm{g} / \mathrm{mL}$ AgNPs. ${ }^{*} p<0.05$ and ${ }^{* *} p<0.01 \mathrm{versus}$ control.

caused dose-dependent GSH reduction in astrocytes, while AgNPs stimulations did not (Fig. S7).

\subsection{Changes in JNK phosphorylation}

JNK is a subfamily of the mitogen activated protein kinase (MAPK) superfamily and plays key role in many cellular events including programmed cell death (apoptosis) (Liu and Lin, 2005). Investigation on JNK phosphorylation in AgNPs and silver ions treated astrocytes showed that AgNPs induced obvious increase in phosphorylated JNK expression at cytotoxic levels $(10,20 \mu \mathrm{g} / \mathrm{mL})$, while low concentrations of AgNPs $(0.01,0.1$ and $1 \mu \mathrm{g} / \mathrm{mL})$ had no effects (Fig. 6). Comparatively, neither non-cytotoxic (0.001, 0.01 and $0.1 \mu \mathrm{g} / \mathrm{mL}$ ) nor cytotoxic levels $(1 \mu \mathrm{g} / \mathrm{mL})$ of silver ions caused JNK phosphorylation in astrocytes, showing silver ions caused cytotoxicity through a distinct way from AgNPs.

\subsection{Cytokines release}

As a potent source of cytokines, astrocytes play a pivotal role in neuroinflammatory responses. The potential influences of chemical exposure on cytokine release were investigated for both AgNPs and silver ions under non-cytotoxic levels. As shown in Fig. S8, the Rat Cytokine Arrays detected multiple cytokines in cell supernates from silver ions $(0.1 \mu \mathrm{g} / \mathrm{mL}, 24 \mathrm{~h})$, AgNPs $(1 \mu \mathrm{g} / \mathrm{mL}, 24 \mathrm{~h})$ exposure groups and the corresponding negative controls. Referring to the coordinates of the Arrays, each target cytokine was characterized and the alterations in the tested cytokines were quantitatively evaluated based on the mean pixel densities. As shown in Table 1 , silver ion stimulation caused no alterations in cytokine release when compared to the negative control. However, AgNPs exposure caused significant increase in the secretion of multiple cytokines including CINC-2 $\alpha / \beta$, CINC-3, fratalkine, Interleukin-10 (IL-10), interferon gamma-induced protein 10 (IP-10), L-selectin and thymus chemokine. These findings suggested that AgNPs could be involved in neuroinflammation instead of silver ions.

\section{Discussion}

Regarding the major species responsible for AgNPs induced toxicities; the perturbation of the released silver ions is commonly believed and has been widely discussed. However, this viewpoint still remains ambiguous as inconsistent evidences are often provided from different scenarios. Substantial comparative toxicity assessments have accordingly been performed using diverse experimental models in vitro and in vivo for diverse AgNPs and silver ions (Bone et al., 2015; Herzog et al., 2013). Most of the studies revealed that ionic silver species caused relatively higher toxicity than AgNPs. For example, in vivo toxicity study showed that the 48-h median lethal concentration $\left(\mathrm{LC}_{50}\right)$ values of PVP
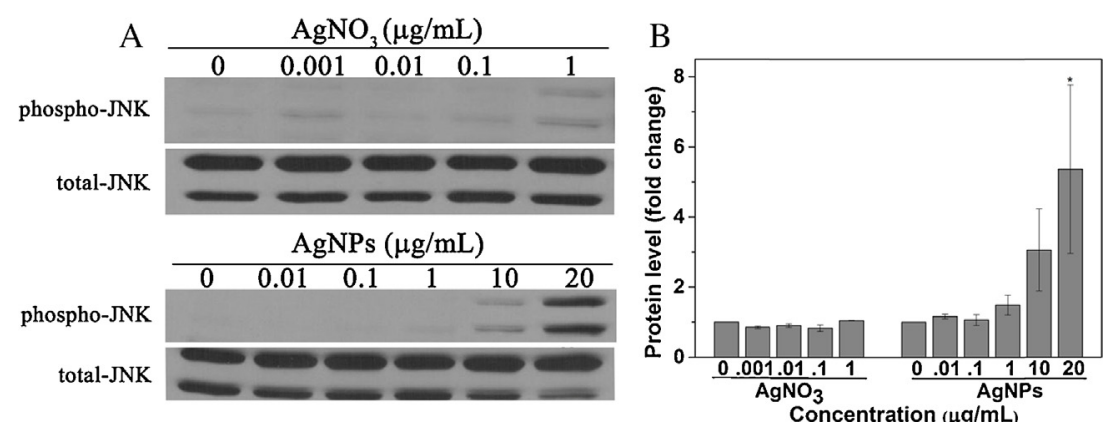

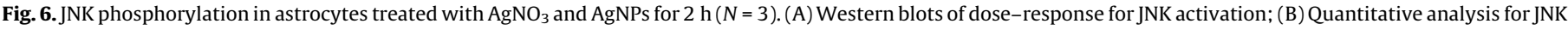
phosphorylation based on gray value of the Western blots. ${ }^{*} p<0.05$ versus control. 
Table 1

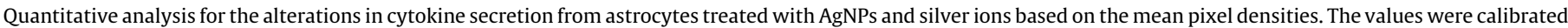
with the negative controls $(N=3) .{ }^{*} p<0.05$ and ${ }^{* *} p<0.01$ versus control.

\begin{tabular}{|c|c|c|c|c|c|}
\hline Cytokine & AgNPs/Control & $\mathrm{Ag}^{+} /$Control & Cytokine & AgNPs/Control & $\mathrm{Ag}^{+} /$Control \\
\hline CINC-1 & $1.34 \pm 0.63$ & $1.00 \pm 0.08$ & IL-10 & $1.51 \pm 0.29^{*}$ & $1.05 \pm 0.01$ \\
\hline CINC- $2 \alpha / \beta$ & $2.58 \pm 0.31^{* *}$ & $1.06 \pm 0.02$ & IL-13 & $1.17 \pm 0.42$ & $1.02 \pm 0.02$ \\
\hline CINC-3 & $1.67 \pm 0.28^{* *}$ & $1.07 \pm 0.02$ & IL-17 & $1.40 \pm 0.48$ & $1.05 \pm 0.02$ \\
\hline CNTF & $1.15 \pm 0.18$ & $1.04 \pm 0.01$ & IP-10 & $1.68 \pm 0.31^{* *}$ & $1.07 \pm 0.12$ \\
\hline Fratalkine & $2.14 \pm 0.64^{*}$ & $1.04 \pm 0.01$ & LIX & $1.07 \pm 0.08$ & $1.04 \pm 0.04$ \\
\hline GM-CSF & $1.08 \pm 0.31$ & $1.03 \pm 0.01$ & L-Selectin & $1.32 \pm 0.04^{* *}$ & $0.99 \pm 0.01$ \\
\hline SLCAM-1 & $1.71 \pm 0.87$ & $0.85 \pm 0.01$ & MIG & $1.39 \pm 0.28$ & $1.04 \pm 0.02$ \\
\hline IFM- $\gamma$ & $1.01 \pm 0.67$ & $1.00 \pm 0.12$ & $\mathrm{MIP}-1 \alpha$ & $1.45 \pm 0.38$ & $1.06 \pm 0.03$ \\
\hline $\mathrm{IL}-1 \alpha$ & $1.21 \pm 0.31$ & $0.94 \pm 0.04$ & $\mathrm{MIP}-3 \alpha$ & $1.10 \pm 0.31$ & $1.00 \pm 0.18$ \\
\hline IL-1 $\beta$ & $1.02 \pm 0.28$ & $1.07 \pm 0.03$ & RANES & $1.48 \pm 0.64$ & $1.47 \pm 0.03$ \\
\hline IL-1 ra & $1.34 \pm 0.52$ & $1.04 \pm 0.02$ & Thymus Chemokine & $1.53 \pm 0.15^{* *}$ & $1.07 \pm 0.06$ \\
\hline IL-2 & $1.14 \pm 0.64$ & $1.00 \pm 0.03$ & TIMP-1 & $1.15 \pm 0.08$ & $1.05 \pm 0.06$ \\
\hline IL-3 & $1.36 \pm 0.34$ & $1.06 \pm 0.03$ & TNF- $\alpha$ & $1.31 \pm 0.44$ & $0.98 \pm 0.01$ \\
\hline IL-4 & $1.39 \pm 0.35$ & $1.04 \pm 0.01$ & VEGF & $1.10 \pm 0.47$ & $1.05 \pm 0.02$ \\
\hline IL-6 & $1.39 \pm 0.48$ & $1.01 \pm 0.01$ & & & \\
\hline
\end{tabular}

coated AgNPs and silver ions were 84 and $25 \mu \mathrm{g} / \mathrm{L}$ in zebrafish (Bilberg et al., 2012). The $24-\mathrm{h} \mathrm{IC} \mathrm{I}_{50}$ values of silver ions and citratecoated AgNPs were 0.5 and $50 \mathrm{mg} / \mathrm{L}$ for HepG2 cells (Vrček et al., 2014). In this study, the $24-\mathrm{h} \mathrm{IC}_{50}$ values based on rat astrocyte cultures also showed that silver ions caused relatively higher cytotoxicity than AgNPs and the difference in the toxicities between these two silver species was approximate 10 folds. This finding is commonly used as the solid evidence for the standpoint that ionic silver species play the dominant role in AgNPs involved toxicities since AgNPs can be regarded as a source slowly releasing silver ions and the particle-specific effect could be negligible. Nevertheless, different opinions emphasizing that ionic silver species are not always able to mask the effects caused by AgNPs per se. In a study on juvenile Japanese medaka (Oryzias latipes), Chae et al. (2009) found that AgNPs showed higher toxicity than ionic silver after 24- and 96-h exposures. Similar result was also observed in primary granule cells in vitro (Yin et al., 2013). Moreover, some other metal nanoparticles like gold nanoparticles may not release metal ions, but caused deleterious biological effects through the induction of oxidative stress (Siddiqi et al., 2012), which hinted the particle-specific effects. Preliminary data in our lab also showed high concentrations of gold nanoparticles did significantly decrease the viability of astrocytes (unpublished data). These findings may bring out the speculation that AgNPs induced toxicological effects are much more complex than the explanation by ionic silver release alone and the particle-specific effect is worthy of being concerned. For the accurate evaluation of the potential distinct toxicities caused by silver ions and AgNPs, non-cytotoxic $(0.0010 .01$ and $0.1 \mu \mathrm{g} / \mathrm{mL}$ for silver ions, 0.01 , 0.1 and $1 \mu \mathrm{g} / \mathrm{mL}$ for AgNPs) and cytotoxic exposure levels ( $1 \mu \mathrm{g} /$ $\mathrm{mL}$ or above for silver ions, $10 \mu \mathrm{g} / \mathrm{mL}$ for AgNPs or above) were designed for both silver species in this study based on their 24-h IC $_{50}$ values $(1.29 \mu \mathrm{g} / \mathrm{mL}$ for silver ions, $9.79 \mu \mathrm{g} / \mathrm{mL}$ for AgNPs) in astrocytes. Unlike the situation at cytotoxic exposure levels, cell proliferation was not influenced when non-cytotoxic levels of silver species were used, which was also guaranteed by similar cell numbers or protein concentrations in the final harvested control and chemical treated cell samples in each experiment (data not shown). The cellular effects were commonly evaluated at the dose difference of 10 folds for them considering toxic equivalents in each assay, for example, the cytotoxic exposure levels of $1 \mu \mathrm{g} / \mathrm{mL}$ for silver ions and $10 \mu \mathrm{g} / \mathrm{mL}$ for AgNPs in Fig. 1C and Fig. 2. The effect of ionic silver from AgNPs suspension at the release ratio of $1-2 \%$ could also be evaluated because the exposure concentrations of silver ions $(0.001 \mu \mathrm{g} / \mathrm{mL}$ to $1 \mu \mathrm{g} / \mathrm{mL})$ covered the possible levels of released silver ions from AgNPs at the current tested range $(0.01-20 \mu \mathrm{g} / \mathrm{mL})$.
The evaluation of extracellular LDH release reveals the integrity of the tested cell membrane. It provides auxiliary evidences for necrosis or apoptosis mediated cytotoxicities as the former form of cell death proceeds with more distinct membrane breakage (Chan et al., 2013). According to the results in this study, silver ions caused the loss of cell membrane integrity in a dose-dependent manner, while AgNPs did not compromise it in the tested concentration range $(0.01-10 \mu \mathrm{g} /$ $\mathrm{mL}$ ). Similar finding was also reported in lung cells, wherein the cellular integrity was not impaired upon agglomerates of AgNPs exposure, but was damaged by a higher concentrated $\mathrm{AgNO}_{3}$ solution (Herzog et al., 2013). This implied the occurrence of distinct toxicological events in astrocytes stimulated by cytotoxic levels of these two silver species, i.e. in contrast to silver ions, AgNPs probably caused apoptosis in astrocytes instead of necrosis. Caspases provide critical links in cell regulatory networks controlling inflammation and cell death (McIlwain et al., 2013). The catalytic activity assay using fluorogenic substrate, Z-DEVD-AFC can evaluate the activation of multiple caspases which may initiate the cell apoptosis. Significant increase of caspase activity in astrocytes stimulated with $10 \mu \mathrm{g} / \mathrm{mL}$ AgNPs confirmed this kind of nanoparticles induced cytotoxicity was mediated through caspase activation (Fig. 3A). This result was consistent with the finding from Baharara et al. (2015), whose research showed AgNPs could induce apoptosis in MCF-7 cells via caspase activation. Comparatively, the role of caspase activation was much less evident in cytotoxicities caused by silver ions as no significant elevation in caspase activity was detected in any of silver ion treatments (Fig. 3A). It has been recently reported that mammalian cells cultivated with toxic doses of nanoparticles or ions, respectively, showed caspase 3/7 activity for the nanoparticles but no activity for the ions. Different mechanisms of cell death were concluded that cells cultivated in the presence of particles apparently suffered apoptosis while cells cultivated with ions died due to necrosis (Sambale et al., 2015). Flow cytometry assay based on FITC labeled Annexin-V and PI double staining provided the direct evaluation for the proportions of the cells going through necrosis and apoptosis. According to the results in Fig. 3B, both $1 \mu \mathrm{g} / \mathrm{mL}$ silver ions and $10 \mu \mathrm{g} / \mathrm{mL}$ AgNPs altered the distribution of the cells in four phases. Specifically, silver ion exposure significantly increased cell proportions in Q1 (cell fragments from necrosis), Q2 (necrosis or late apoptosis and) and Q4 (early apoptosis), while AgNPs stimulation obviously elevated the cell amount in Q4. The phenomenon of necrosis was more distinct in silver ions treated group than AgNPs, showing the cell death events induced by these two silver species were different. 
The cellular internalization of silver through diffusion or endocytosis is believed to be the crucial prerequisite for the biological effects induced by both ionic and particulate silver forms (AshaRani et al., 2009). Investigation on intracellular silver content (Fig. 4B) indicated that when the exposure concentration was set at the same level for both silver species $(1 \mu \mathrm{g} / \mathrm{mL}$ ), silver ions entered into the astrocytes quicker than AgNPs within short exposure time $(4 \mathrm{~h})$, while relatively higher content of silver was retained in the cells during longer period ( $24 \mathrm{~h}$ ) for AgNPs. Regarding the cellular uptake of silver ions, some transmembrane proteins, as the potential ion transporters might play important roles. Some heavy metal transporting P-type ATPase (Havelaar et al., 1998) and CopBATPase (Solioz and Odermatt, 1995) were demonstrated for silver ion transport through plasma membrane. In contrast to ion channels, it was also understandable that silver ions might directly diffuse into the cells through the compromised membrane integrity as evidenced by increased extracellular LDH release in silver ion groups (Fig. 1B). However, 24-h exposure by $1 \mu \mathrm{g} / \mathrm{mL}$ silver ions could cause acute cytotoxicity which suppressed the high accumulation of this silver form in the cells. In contrast, the formation of phagocytotic vesicles shown in Fig. 4C-2 suggested that encapsulation of AgNPs by cell membrane and subsequent endocytosis could be the dominant process for the cellular uptake of AgNPs and the particulate silver were prone to remain in cells due to the unimpaired cell membrane integrity. The separate routes of cellular internalization and differing in vivo fates of $\mathrm{Ag}$ delivered in dissolved and nanoparticle forms were also found in gut epithelia and an endocytotic pathway was suggested to be a key route of cellular uptake for AgNPs (García-Alonso et al., 2011). Nevertheless, the endocytosis inhibitors chloroquine or amiloride lowered AgNPs accumulation in astrocytes by $30 \%$ and some other factor like temperature-dependent process was most likely involved in endocytotic pathways (Luther et al., 2011). Similar to the finding from Luther et al. (2012), the cellular internalized silver was correlated with the exposure concentrations of silver ions and AgNPs, demonstrating the toxicity difference in astrocytes between these two silver species was not due to the disparity in the amounts of internalized silver, but their forms. Accordingly, the findings in this study provided useful evidences for the explanation of the potential toxicological modes induced by these two silver species.

As pointed out by AshaRani et al. (2009), AgNPs could increase ROS production in a dose-dependent manner through the disruption of the mitochondrial respiratory chain after cellular internalization in human cells. Similarly, in this study, the intracellular ROS generation was found to be induced in both concentration and exposure time related manners in AgNPs stimulated astrocytes (Fig. 5). Interestingly, this effect was independent of silver ion release as ionic silver did not cause any effect on cellular DCFH oxidation. This finding was distinct from the common sense that silver ions could induce oxidative stress (Cortese-Krott et al., 2009), which might infer that different toxicological routes existed in different experimental models. Less intracellular ROS generation was also observed in silver ions treated nitrifying cultures when compared to AgNPs groups (Choi and $\mathrm{Hu}, 2008$ ). Antioxidant GSH also plays important roles in the regulation of antioxidative defense system in cells (Mytilineou et al., 2002) and the antibacterial activities of AgNPs due to the binding between thiol and silver ions (Liu et al., 2010) might provide an alternative way for the induction of oxidative stress. Nevertheless, the comparison on cellular GSH alterations in astrocytes showed that silver ions caused GSH depletion in a dose-related manner, which was in contrast to AgNPs (Fig. S7). Similar results were also reported by Luther et al. (2011), showing AgNPs induced oxidative stress by evoking ROS generation in astracytes, rather than GSH depletion. It is well known that ROS and the resulting oxidative stress play a pivotal role in apoptosis (Kanna and Jain, 2000). The elevation of intracellular ROS was thus well consistent with the finding that AgNPs significantly induced cell apoptosis as indicated by the results from extracellular LDH assay, caspase activation and flow cytometry. One of the consequences of oxidative stress is the phosphorylation of MAPKs (Jayakumar et al., 2006) and JNKs promote apoptosis by the upregulating proapoptotic genes directly or by modulating the activities of mitochondrial pro- and anti-apoptotic proteins through distinct phosphorylation events (Danny et al., 2008). AgNPs exposure was found to induce ROS production in human epithelial embryonic cells and an early response of JNK phosphorylation (Rinna et al., 2015). In this study, significant increase in JNK phosphorylation concomitant with ROS generation was evidently involved in astrocytes apoptosis upon cytotoxic levels of AgNPs treatments ( 10 and $20 \mu \mathrm{g} / \mathrm{mL}$ ). Nevertheless, silver ions caused cell death events were free from JNK phosphorylation (Fig. 6), which gave us a new insight for the difference in the toxicological modes of silver ions and AgNPs.

As one of the two primary types of macroglial cells in the brain, astrocytes can be activated upon endogenous or exogenous insults, thus causing the release of various inflammatory factors and undergoing morphological changes (Mayer et al., 2013). The potential of AgNPs stimulation on astrocytes at non-cytotoxic levels would help to interpret the compromised integrity of brainblood barrier (BBB) and translocation of the nanoparticles in the brain because astrocytes compose a significant component of this barrier. The investigation on the possible influences of AgNPs on cytokines and chemokines release in astrocytes using the Rat Cytokine Arrays showed that AgNPs exposure increased multiple cytokines release, while silver ions had no effects (Fig. S8, Table 1). The cytokines with significant changes are involved in multiple cellular functions. For example, CINC- $2 \alpha / \beta$, CINC-3 and thymus chemokine play important roles in neutrophil recruitment (Nakagawa et al., 1994). Fratalkine mediates leukocyte adhesion (Jones et al., 2010) and IL-10 is an anti-inflammatory cytokine (Braat et al., 2006). IP-10 and L-selectin attribute to diverse roles in neuroinflammation as well (Dufour et al., 2002; Kohn et al., 2012). Previous studies showed that AgNPs increased the permeability of brain microvessel endothelial cells through the release of proinflammatory mediators, which was responsible for AgNPs induced BBB inflammation (Trickler et al., 2010). Recent researches on inflammatory and neurodegenerative responses revealed that AgNPs could also induce IL-1 $\beta$ secretion and increase the gene expression of $\mathrm{C}-\mathrm{X}-\mathrm{C}$ motif chemokine 13 in murine brain ALT astrocytes (Huang et al., 2015). Accordingly, it was confirmed that AgNPs stimulation could mediate cellular biological functions through altering inflammatory factors secretion and this effect was independent of silver ions as indicated in Table 1.

Overall, AgNPs and silver ions induced neurotoxicities in rat cerebral astrocytes through distinct pathways. AgNPs caused cell apoptosis by inducing intracellular ROS generation coupled with JNK phosphorylation. In contrast, silver ions predominantly led to cell necrosis via compromising the cell membrane integrity and binding with cellular thiol groups directly. Non-cytotoxic level of AgNPs induced neuroinflammation through the regulation of cytokine secretion in astrocytes and this effect was free from silver ion release, indicating particle-specific effect played roles in AgNPs mediated neurotoxicities. Accordingly, the understanding for the toxicological mechanisms of AgNPs needs to be straightened from the overemphasis on the role of released ionic silver.

\section{Conflict of interest}

The authors declare that there are no conflicts of interest. 


\section{Transparency document}

The Transparency document associated with this article can be found in the online version.

\section{Acknowledgements}

This research was sponsored by the National Basic Research Program of China (2015CB453102), Major International (Regional) Joint Project (21461142001), Strategic Priority Research Program of the Chinese Academy of Science (14040302), National Natural Science Funds of China (21477153, 21137002, 21307124).

\section{Appendix A. Supplementary data}

Supplementary data associated with this article can be found, in the online version, at http://dx.doi.org/10.1016/j.neuro.2015.09.007.

\section{References}

AshaRani, P.V., Low Kah Mun, G., Hande, M.P., Valiyaveettil, S., 2009. Cytotoxicity and genotoxicity of silver nanoparticles in human cells. ACS Nano 3, 279-290. http://dx.doi.org/10.1021/nn800596w.

Baharara, J., Namvar, F., Ramezani, T., Mousavi, M., Mohamad, R., 2015. Silver nanoparticles biosynthesized using Achillea biebersteinii flower extract: apoptosis induction in MCF-7 cells via caspase activation and regulation of Bax and Bcl-2 gene expression. Molecules 20, 2693-2706. http://dx.doi.org/ 10.3390/molecules20022693.

Bilberg, K., Hovgaard, M.B., Besenbacher, F., Baatrup, E., 2012. In vivo toxicity of silver nanoparticles and silver ions in zebrafish (Danio rerio). J. Toxicol. 293784, 1-9. http://dx.doi.org/10.1155/2012/293784.

Bone, A.J., Matson, C.W., Colman, B.P., Yang, X., Meyer, J.N., Di Giulio, R.T., 2015. Silver nanoparticle toxicity to Atlantic killifish (Fundulus Heteroclitus) and Caenorhabditis elegans: a comparison of mesocosm, microcosm and conventional laboratory studies. Environ. Toxicol. Chem. 34, 275-282.

Braat, H., Rottiers, P., Hommes, D.W., Huyghebaert, N., Remaut, E., Remon, J.P., van Deventer, S.J., Neirynck, S., Peppelenbosch, M.P., Steidler, L., 2006. A phase I trial with transgenic bacteria expressing interleukin-10 in Crohn's disease. Clin. Gastroenterol. Hepatol. 4, 754-759. http://dx.doi.org/10.1016/j. cgh.2006.03.028.

Castranova, V., 2011. Overview of current toxicological knowledge of engineered nanoparticles. J. Occup. Environ. Med. 53, S14-S17. http://dx.doi.org/10. 1097/JOM.0b013e31821b1e5a.

Chae, Y.J., Pham, C.H., Lee, J., Bae, E., Yi, J., Gu, M.B., 2009. Evaluation of the toxic impact of silver nanoparticles on Japanese medaka (Oryzias latipes). Aqua Toxicol. 94, 320-327. http://dx.doi.org/10.1016/j.aquatox.2009.07.019.

Chan, F.K., Moriwaki, K., De Rosa, M.J., 2013. Detection of necrosis by release of lactate dehydrogenase (LDH) activity. Methods Mol. Biol. 979, 65-70. http:// dx.doi.org/10.1007/978-1-62703-290-2_7.

Chen, X., Schluesener, H.J., 2008. Nanosilver: a nanoproduct in medical application. Toxicol. Lett. 176, 1-12. http://dx.doi.org/10.1016/j.toxlet.2007. 10.004.

Chen, Y., Swanson, R.A., 2003. Astrocytes and brain injury. J. Cerebr. Blood F Met. 23, 137-149, http://dx.doi.org 10.1097/01.WCB. 0000044631.80210.3C.

Choi, O., Hu, Z., 2008. Size dependent and reactive oxygen species related nanosilver toxicity to nitrifying bacteria. Environ. Sci. Technol. 42, 45834588. http://dx.doi.org/10.1021/es703238h.

Cortese-Krott, M.M., Münchow, M., Pirev, E., Hessner, F., Bozkurt, A. Uciechowski, P., Pallua, N., Kröncke, K.D., Suschek, C.V., 2009. Silver ions induce oxidative stress and intracellular zinc release in human skin fibroblasts. Free Radic. Biol. Med. 47, 1570-1577. http://dx.doi.org/10.1016/j. freeradbiomed.2009.08.023.

Danny, N., Dhanasekaran, E., Premkumar, R., 2008. JNK signaling in apoptosis. Oncogene 27, 6245-6251. http://dx.doi.org/10.1038/onc.2008.301.

Dufour, J.H., Dziejman, M., Liu, M.T., Leung, J.H., Lane, T.E., Luster, A.D., 2002. IFN-gamma-inducible protein 10 (IP-10; CXCL10)-deficient mice reveal a role for IP-10 in effector T cell generation and trafficking. J. Immunol. 168, 3195-3204. http://dx.doi.org/10.4049/jimmunol.168.7.3195.

EPA, 2010. State of the Science Literature Review. Everything Nanosilver and More, US. Available from: http://www.epa.gov.

García-Alonso, J., Khan, F.R., Misra, S.K., Turmaine, M., Smith, B.D., Rainbow, P.S., Luoma, S.N., Valsami-Jones, E., 2011. Cellular internalization of silver nanoparticles in gut epithelia of the estuarine polychaete nereis diversicolor. Environ. Sci. Technol. 45, 4630-4636, http://dx.doi.org/10.1021/es2005122.

Haase, A., Rott, S., Mantion, A., Graf, P., Plendl, J., Thünemann, A.F., Meier, W.P., Taubert, A., Luch, A., Reiser, G., 2012. Effects of silver nanoparticles on primary mixed neural cell cultures: uptake, oxidative stress and acute calcium responses. Toxicol. Sci. 126, 457-468. http://dx.doi.org/10.1093/ toxsci/kfs003.
Havelaar, A.C., de Gast, I.L., Snijders, S., Beerens, C.E.M.T., Mancini, G.M.S., Verheijen, F.W., 1998. Characterization of a heavy metal ion transporter in the lysosomal membrane. FEBS Lett. 436, 223-227, http://dx.doi.org/ 10.1016/S0014-5793(98) 01133-8.

Herzog, F., Clift, M.J., Piccapietra, F., Behra, R., Schmid, O., Petri-Fink, A., RothenRutishauser, B., 2013. Exposure of silver-nanopartilces and silver-ions to lung cells in vitro at the air-liquid interface. Part Fibre Toxicol. 10, 1-14. http://dx.doi.org/10.1186/1743-8977-10-11.

Hohnholt, M.C., Geppert, M., Luther, E.M., Petters, C., Bulcke, F., Dringen, R. 2013. Handling of iron oxide and silver nanoparticles by astrocytes. Neurochem. Res. 38, 227-239. http://dx.doi.org/10.1007/ s11064-012-0930-y.

Huang, C.L., Hsiao, I.L., Lin, H.C., Wang, C.F., Huang, Y.J., Chuang, C.Y., 2015. Silver nanoparticles affect on gene expression of inflammatory and neurodegenerative responses in mouse brain neural cells. Environ. Res. 136, 253-263. http://dx.doi.org/10.1016/j.envres.2014.11.006.

Jayakumar, A.R., Panickar, K.S., Murthy ChR, Norenberg, M.D., 2006. Oxidative stress and mitogen-activated protein kinase phosphorylation mediate ammonia-induced cell swelling and glutamate uptake inhibition in cultured astrocytes. J. Neurosci. 26, 4774-4784. http://dx.doi.org/10.1523/JNEUROSCI. 0120-06.2006.

Jones, B.A., Beamer, M., Ahmed, S., 2010. Fractalkine/CX3CL1: a potential new target for inflammatory diseases. Mol. Interv. 10, 263-270. http://dx.doi.org/ 10.1124/mi.10.5.3.

Kanna, K., Jain, S.K., 2000. Oxidative stress and apoptosis. Pathophysiology 7. 153-163. http://dx.doi.org/10.1016/S0928-4680(00)00053-5.

Kathryn, A.W., Robert, W., Donnell, O., 2010. Primary culture of rat cerebral astrocytes. Biol. Honor Thesis 1-20. http://josm.geneseo.edu/theses/ Weiss-02.pdf.

Kawata, K., Osawa, M., Okabe, S., 2009. In vitro toxicity of silver nanoparticles at noncytotoxic doses to HepG2 human hepatoma cells. Environ. Sci. Technol. 43, 6046-6051. http://dx.doi.org/10.1021/es900754q.

Kohn, L.A., Hao, Q.L., Sasidharan, R., Parekh, C., Ge, S., Zhu, Y., Mikkola, H.K. Crooks, G.M., 2012. Lymphoid priming in human bone marrow begins before expression of CD10 with upregulation of L-selectin. Nat. Immunol. 13, 963971. http://dx.doi.org/10.1038/ni.2405.

Liu, J., Lin, A., 2005. Role of JNK activation in apoptosis: a double-edged sword. Cell Res. 15, 36-42. http://dx.doi.org/10.1038/sj.cr.7290262.

Liu, J., Sonshine, D.A., Shervani, S., Hurt, R.H., 2010. Controlled release of biologically active silver from nanosilver surfaces. ACS Nano 4, 6903-6913. http://dx.doi.org/10.1021/nn102272n.

Luther, E.M., Koehler, Y., Diendorf, J., Epple, M., Dringen, R., 2011. Accumulation of silver nanoparticles by cultured primary brain astrocytes. Nanotechnology 22, 1-11. http://dx.doi.org/10.1088/0957-4484/22/37/375101.

Luther, E.M., Schmidt, M.M., Diendorf, J., Epple, M., Dringen, R., 2012 Upregulation of metallothioneins after exposure of cultured primary astrocytes to silver nanoparticles. Neurochem. Res. 37, 1639-1648. http://dx. doi.org/10.1007/s11064-012-0767-4.

Mayer, C.L., Huber, B.R., Peskind, E., 2013. Traumatic brain injury, neuroinflammation, and post-traumatic headaches. Headache 53, 15231530. http://dx.doi.org/10.1111/head.12173.

McIlwain, D.R., Berger, T., Mak, T.W., 2013. Caspase functions in cell death and disease. Cold Spring Harb. Perspect. Biol. 5, 1-28. http://dx.doi.org/10.1101/ cshperspect.a00865.

McShan, D., Ray, P.C., Yu, H., 2014. Molecular toxicity mechanism of nanosilver. J. Food Drug Anal. 22, 116-127. http://dx.doi.org/10.1016/j.jfda.2014.01.010.

Mytilineou, C., Kramer, B.C., Yabut, J.A., 2002. Glutathione depletion and oxidative stress. Parkinsonism Relat. Disord. 8, 385-387. http://dx.doi.org/10. 1016/S1353-8020(02)00018-4.

Nakagawa, H., Komorita, N., Shibata, F., Ikesue, A., Konishi, K., Fujioka, M., Kato, H., 1994. Identification of cytokine-induced neutrophil chemoattractants (CINC), rat GRO/CINC-2 alpha and CINC-2 beta, produced by granulation tissue in culture: purification, complete amino acid sequences and characterization. Biochem. J. 301, 545-550. http://www.biochemj.org/bj/301/ 0545/3010545.pdf.

Nate, S., 2013. Nanosilver: weighing the risks and benefits. Environ. Health Persp. 121,. a220-5. http://dx.doi.org/10.1289/ehp.121-a220.

Rinna, A., Magdolenova, Z., Hudecova, A., Kruszewski, M., Refsnes, M., Dusinska, M., 2015. Effect of silver nanoparticles on mitogen-activated protein kinases activation: role of reactive oxygen species and implication in DNA damage. Mutagenesis 30, 59-66. http://dx.doi.org/10.1093/mutage geu057.

Sambale, F., Wagner, S., Stahl, F., Khaydarov, R.R., Scheper, T., Bahnemann, D., 2015. Investigations of the toxic effect of silver nanoparticles on mammalian cell lines. J. Nanomater. 136765, 1-9. http://dx.doi.org/10.1155/2015/ 136765.

Sharma, H.S., Ali, S.F., Hussain, S.M., Schlager, J.J., Sharma, A., 2009. Influence of engineered nanoparticles from metals on the blood-brain barrier permeability, cerebral blood flow, brain edema and neurotoxicity. An experimental study in the rat and mice using biochemical and morphological approaches. J. Nanosci. Nanotechnol. 9, 5055-5072. http://dx. doi.org/10.1166/jnn.2009.GR09.

Siddiqi, N., Abdelhalim, M.A.K., El-Ansary, A.K., Alhomida, A.S., Ong, W.Y., 2012 Identification of potential biomarkers of gold nanoparticle toxicity in rat brains. J. Neuroinflamm. 9, 123-129. http://dx.doi.org/10.1186/ 1742-2094-9-123. 
Solioz, M., Odermatt, A., 1995. Copper and silver transport by CopB-ATPase in membrane vesicles of Enterococcus hirae. J. Biol. Chem. 270, 9217-9221, http://dx.doi.org/10.1074/jbc.270.16.9217.

Szydlowska, K., Gozdz, A., Dabrowski, M., Zawadzka, M., Kaminska, B., 2010. Prolonged activation of ERK triggers glutamate-induced apoptosis of astrocytes: neuroprotective effect of FK506. J. Neurochem. 113, 904-918. http://dx.doi.org/10.1111/j.1471-4159.2010.06656.x.

Tang, J., Xiong, L., Wang, S., Wang, J., Liu, L., Li, J., Yuan, F., Xi, T., 2009. Distribution, translocation and accumulation of silver nanoparticles in rats. J. Nanosci. Nanotechnol. 9, 4924-4932. http://dx.doi.org/10.1166/jnn.2009.1269.

Trickler, W.J., Lantz, S.M., Murdock, R.C., Schrand, A.M., Robinson, B.L., Newport, G.D., Schlager, J.J., Oldenburg, S.J., Paule, M.G., Slikker Jr., W., Hussain, S.M., Ali, S.F., 2010. Silver nanoparticle induced blood-brain barrier inflammation and increased permeability in primary rat brain microvessel endothelial cells. Toxicol. Sci. 118, 160-170. http://dx.doi.org/10.1093/toxsci/kfq244.

Vrček, I.V., Zuntar, I., Petlevski, R., Pavičić, I., Dutour Sikirić, M., Curlin, M. Goessler, W., 2014. Comparison of in vitro toxicity of silver ions and silver nanoparticles on human hepatoma cells. Environ. Toxicol. 22081, 1-14. http://dx.doi.org/10.1002/tox.22081.
Wilson center., 2014. Project on Emerging Nanotechnologies. Consumer Products Inventory, Washington, DC. Available from: http://www. nanotechproject.org/cpi.

Win-Shwe, T.T., Fujimaki, H., 2011. Nanoparticles and neurotoxicity. Int. J. Mol. Sci. 12, 6267-6280. http://dx.doi.org/10.3390/ijms12096267.

Wright, P.C., Qin, H., Choi, M.M., Chiu, N.H., Jia, Z., 2014. Carbon nanodots interference with lactate dehydrogenase assay in human monocyte THP-1 cells. SpringerPlus 3, 615-619. http://dx.doi.org/10.1186/2193-1801-3-615.

Xiu, Z.M., Zhang, Q.B., Puppala, H.L., Colvin, V.L., Alvarez, P.J., 2012. Negligible particle-specific antibacterial activity of silver nanoparticles. Nano Lett. 12, 4271-4275. http://dx.doi.org/10.1021/nl301934w.

Yin, N., Liu, Q., Liu, J., He, B., Cui, L., Li, Z., Yun, Z., Qu, G., Liu, S., Zhou, Q., Jiang, G., 2013. Silver nanoparticle exposure attenuates the viability of rat cerebellum granule cells through apoptosis coupled to oxidative stress. Small 9, 1831-1841. http://dx.doi.org/10.1002/smll.201202732.

Ziemińska, E., Stafiej, A., Strużyńska, L., 2014. The role of the glutamatergic NMDA receptor in nanosilver-evoked neurotoxicity in primary cultures of cerebella granule cells. Toxicology 315, 38-48. http://dx.doi.org/10.1016/j. tox.2013.11.008 